Accepted by the Journal of Business Ethics for the Special Issue on:

Corporate Social Responsibility Implementation

Implementing CSR through partnerships: understanding the selection, design and institutionalisation of nonprofit-business partnerships*

Dr. Maria May Seitanidi

Lecturer

Brunel Business School

Brunel University, Uxbridge UB8 3PH, UK

Email: mmayseitanidi@yahoo.com

Tel. 00447919440088

Prof. Andrew Crane

George R. Gardiner Professor of Business Ethics

Schulich School of Business, Room N-212

York University

4700 Keele Street

Toronto, Ontario

Canada M3J 1P3

Email: acrane@schulich.yorku.ca

T: (416) 736-2100 ext 30190

F: (416) 736-5195

* The authors would like to thank the anonymous reviewers for their valuable remarks and suggestions and Ms Amelia Clarke at the Desautels Faculty of management at McGill University for her contribution and insightful remarks on the process models of collaboration. 


\title{
Implementing CSR through partnerships: understanding the selection, design and institutionalisation of nonprofit-business partnerships
}

\begin{abstract}
Partnerships between businesses and nonprofit organisations are an increasingly prominent element of corporate social responsibility implementation. The paper is based on two in depth partnership case studies (Earthwatch-Rio Tinto and Prince's Trust-Royal Bank of Scotland) that move beyond a simple stage model to reveal the deeper level micro-processes in the selection, design and institutionalisation of business-NGO partnerships. The suggested practice-tested model is followed by a discussion that highlights management issues within partnership implementation and a practical Partnership Test to assist managers in testing both the accountability and level of institutionalisation of the relationship in order to address any possible skill gaps. Understanding how CSR partnerships are implemented in practice contributes to the broader CSR and partnership literatures a context specific level of detail in a systematic way that allows for transferable learning in both theory and practice.
\end{abstract}

KEY WORDS: Partnerships, corporate social responsibility, NGO, implementation, institutionalisation, micro-processes. 


\section{Introduction}

Organizations faced with CSR problems and challenges need effective ways of

implementing CSR programmes and initiatives. However, whilst there is an emerging consensus that CSR can and should be implemented in organizations, CSR is currently characterised by many unsystematic practices, i.e. constellations of arrangements that are fit for purpose within specific contexts but which lack transferability and sustainability. Nowhere is this more evident than in the area of business (BUS) and non profit organization (NPO) partnership. Such cross-sector partnerships have been one of the most exciting and challenging ways that organizations have been implementing CSR in recent years (Seitanidi and Ryan, 2007). BUS-NPO partnership is one of the four different types of partnerships (Figure 1) that represent what is referred to as 'social partnerships' (Waddock 1988; Googins \& Rochlin 2000) or as recently named 'crosssector partnerships that address social issues’ (CSSPs) (Selsky and Parker 2005:1).

\section{Insert Figure 1 here}

According to Waddock (1988:18) social partnerships are:

"A commitment by a corporation or a group of corporations to work with an organisation from a different economic sector (public or nonprofit). It involves a commitment of resources - time and effort - by individuals from all partner organisations. These individuals work co-operatively to solve problems that affect them all. The problem can be defined at least in part as a social issue; its solution will benefit all partners. Social partnership addresses issues that extend beyond organisational boundaries and traditional goals and lie within the traditional realm of public policy - that is, in the social arena. It requires active rather than passive involvement from all parties. Participants must make a resource commitment that is more than merely monetary".

Social partnerships as "social problem-solving mechanisms among organisations" (Waddock, 1989: 79) primarily address social issues (e.g. education, health, environment) by combining organisational resources in order to offer solutions that benefit partners, as well as society at large. As such, BUS-NPO partnerships represent the alignment of strategic business interests with societal expectations, as expressed through NPOs (Covey and Brown, 2001; Austin 2000). Such partnerships therefore offer considerable insight 
into the dynamics of CSR implementation, not least because BUS-NPO partnerships are typically seen by both sets of institutions as instantiations of 'doing' CSR. However, the dynamic nature of social problems results in inherent difficulties to arrive at solutions (McCann, 1983), especially solutions that are that are accountable and sustainable. Furthermore "the scale and duration of such problems also mean that a great many social actors-individuals, groups, and organisations will be affected” (McCann, 1983: 177).

Therefore, despite their great attraction for the various sectors involved, the ways that BUS-NPO partnerships can and should be implemented are not well understood. Whilst we know from existing stage models that partnerships move from selection to design and then institutionalisation (Selsky and Parker, 2005), one of the ways to overcome implementation difficulties (Pressman and Wildavsky, 1973) is to examine not only the stages of the process (McCann, 1983) but to attempt to penetrate a stage model by introducing micro-processes that reveal the quality of the efforts and a deeper understanding of these efforts (McCann, 1983a). The aim of this paper is therefore to unpack these different stages in order to reveal the components that make up each of the stages of implementation. This is a critical step in the development of a more refined process model of partnership implementation that could inform theory and practice in important new ways. For instance, it can help us to understand how organizations might effectively select potential partners, how they can go about designing suitable partnership arrangements, and how partnerships can be developed over time to ensure long term sustainability and success.

In so doing, the paper offers new ways of conceptualising the CSR implementation process through the lens of partnership implementation and management. Waddock (1989) remarked eighteen years ago on the need for more studies on the processes of interactions across organisations from different economic sectors but also for the need to provide more details. More recently, Clarke (2007a) commented on the enduring lack of studies on partnership implementation. Although they both suggest models applied to the partnership phenomenon (Clarke, 2007b; Waddock, 1989) neither has addressed the micro-process level of detail that is required in order to deepen our understanding. The context specific micro-process of detail transcend beyond the time progression issues suggested by linear (Clarke, 2007a) and evolutionary (Waddock, 1989) process models 
allowing us to address issues such as legitimacy and accountability of collaborative actions, the dynamics between the different organisational actors and to what extent social actors have considered the adoption of indicators for performance evaluation. One of the contributions of this paper is that it is not putting forward a theory-informed stage model but rather it presents a practice-tested model that can inform theory and can potentially be transferred to other partnerships.

\section{Implementing CSR through partnerships}

In recent years, a small but growing body of literature has emerged to analyse BUS-NPO partnership and its role in effecting CSR. This has ranged from studies that have emphasised the strategic purpose of those relationships (Warner and Sullivan, 2004; Loza, 2004; Bendell and Murphy, 2000; Waddell, 2000; Moser, 2001; Stafford and Hartman, 2001; Nelson and Zadek, 2000; Waddock, 1988) moving to legal and ethical aspects (Hardis, 2003; Tully, 2004; Crane, 2000) and more recently highlighting the societal implications of BUS-NPO arrangements (Hamman and Acutt, 2003; Millar et al, 2004; Tully, 2004).

When business and non-profit organizations come together to address CSR problems, the subsequent partnerships inevitably emerge in different forms and over different stages (Selsky and Parker, 2005). According to Bryson, Crosby and Middleton-Stone (2006), the design and implementation of partnerships can be broadly categorised into five main areas: initial conditions; structure and governance; process; contingencies and constraints; and outcomes and accountabilities. For example, the literature suggests that there are differences in the structures of cross-sector relationships ranging from formal agreements (Austin, 2000) to informal loose collaborations (Berger et al, 2004). Moreover, implementation tends to occur through discrete phases or steps. Googins and Rochlin (2000:133) for example refer to the 'critical steps' within the process of partnership building and suggest six steps: 1/ defining clear goals, 2/ obtaining senior level commitment, 3/ engaging in frequent communication, 4/ assigning professional to lead the work, 5/ sharing the commitment of resources and 6/ evaluating progress/result. Andriof (2001: 224) refers to the 'four Ps' of stakeholder partnership building: the purpose of partnerships, the pact between the partners, the power relationships within the partners and the process of partnerships evolution. As such, a number of either 
prescriptive or descriptive steps of partnership building exist within the literature (Berger et al, 2004; Wilson and Charlton, 1997; Westley and Vredenburg, 1997), where their common characteristic appears to be the chronological sequence of evolution (Selsky and Parker, 2005).

One way of designating these steps is to conceive of implementation taking place through the stages of selection, design, and institutionalisation. This view of implementation regards implementation as something that doesn’t happen once a strategy has been planned and designed, but is a fundamental part of the ongoing strategy process (Mintzberg, 1993) The identification of such stages is an important element in the development of process models of implementation. However in order to facilitate greater learning about partnership implementation, we need to go beyond these broad brush identification of stages and develop a clearer picture of the processes that comprise them, such as how selection can and should happen, what steps do managers have to consider in the design of suitable CSR partnerships, and how does institutionalisation occur. As Godfrey and Hatch, 2007: 87) remark: "in a world that is increasingly global and pluralistic, progress in our understanding of CSR must include theorizing around the micro-level processes practicing managers engage in when allocating resources toward social initiatives”.

Identifying the stages and processes involved in implementing a strategic initiative such as a BUS-NPO partnership helps us to comprehend what are highly complex initiatives (Bryson, Crosby and Middleton-Stone, 2006). As with other strategic initiatives, such as organizational change, new product development, or business-business collaboration, managers need to be prepared for the challenges that lay in store when embarking on such an enterprise. This is not to say that such process models can necessarily then be used to plan a foolproof strategy for collaboration, but they can offer considerable insight into how partnership implementation emerges over time and the types of threats and barriers that might need to be overcome in the process. This paper seeks to provide such a model by investigating in considerable detail the implementation of BUS-NPO partnership in two cases dealing with CSR initiatives in the UK. By providing new insight on the way that partnership implementation evolves in practice, we will identify the components of 
selection, design, and institutionalisation that typically feature in partnerships, and thereby explore the benefits and drawbacks of different approaches.

\section{Methods}

The two case studies (Earthwatch ${ }^{1}$-Rio Tinto Partnership and Prince’s Trust-Royal Bank of Scotland Partnership) were developed between July 2002 and January 2004 as part of a broader research study on NPO-BUS Partnerships in the UK. The case studies presented in this paper consisted of 16 interviews $^{2}$ and 24 interviews respectively across the two partner organisations. Further organisational documents such as annual and internal reports supplemented the interviews.

The criteria employed to select the cases were: 1/ the scope of activities (international/national); 2/ the purpose of the partnership (focusing on an environmental or social issue); 3/ type of resources exchanged across the partner organisations (financial/non-financial); 4/ the type of organisational reputation (a combination of three level scales of high-medium-low and positive-neutral-negative were employed based on the media content assessed for the original research) and 5/ the style of activity among the two organisations which here was constant (collaborative interaction) since the issue under examination was partnership implementation. Table 1 below summarises the different criteria.

\section{Insert Table 1 here}

The interviews were recorded, transcribed and confirmed by each interviewee allowing for marking sections as 'off the record' (in addition to sections noted as 'off the record' during the interviews) due to the sensitivity of the material, the use of the real names of organisations, as well as original job titles of informants. Such 'off the record' requests were granted in full in order to protect the confidentiality of the interviewees by masking their job titles. The final transcripts were imported into NVivo which was used to manage the data analysis process. A total of 837 nodes were initially developed, and these were then gradually collapsed into common themes grouped around the chronological stages of partnerships. Within the two case studies the aim was to arrive at theoretical rather than statistical generalisations (Ragin 1991) and to develop critical thinking (Alvarez et al, 
1990) focused on the process of partnership building and in particular on partnership management at the implementation stage.

The analytic framework adopted was that of a contextualist approach following Pettigrew (1985) which highlights the importance of studying organisational change in three dimensions: context, content and process. Semi-structured interviews were employed, in particular "problem centred interviews” which according to Flick (1998) are used in order to obtain subjective viewpoints about a social problem. The unit of analysis within this paper is that of the 'partnership' rather than that of an organisation - i.e. the sample is two case studies of two partnerships, rather than four cases studies of four organizations. The important point to recognise here is that we were interested in revealing the interactions between the partners, as well as the different perspectives on the partnership provided by organizational members. Data collection and analysis was thus driven by its contribution to our understanding of the partnership itself rather than of the partner organizations more broadly. All descriptions used for the conceptualisation of stages and processes are grounded within the interviewee's comments. Finally, brief information about each organisation is presented in the appendix along with brief descriptions about the content of the partnerships which are indicative of the spectrum of operations and resources required.

\section{The selection, design, and institutionalisation of CSR partnerships}

\section{Partnership Selection}

As we have emphasised above, partnership implementation does not begin after a strategy has been planned and designed, but is integral to its selection in the first place. The first phase of partnership implementation is therefore Partnership Selection, which commences with the decision to choose 'partnership' as the preferred associational form rather than other forms of community involvement (Seitanidi and Ryan, 2007). This decision is usually influenced by the strategic objectives of each organisation (for example "improve corporate reputation by improving operations performance”) and by social trends as testified by an executive at Rio Tinto, suggesting that the partnership was “a slightly sexy subject at the time” (Corporate Relations Advisor, Rio Tinto). 
Assessing the options of possible partners is the next step and involves talking to various non-profit organisations (or BUSs in the case of a NPO) in order to determine the potential of each option:

"I spent a lot of time over a period of some years discussing Rio Tinto and issues surrounding the mining industry with environmental organisations, particularly in the UK, so we knew quite a lot of environmental organisations quite well. So in some cases it wasn't necessary the best way of setting up partnerships, but it made sense to try and develop the first partnerships with the organisations that we knew very well, like Earthwatch, so that's what we did.” (Corporate Relations Manager, Rio Tinto)

"... and that's when I think the bank was really starting to look at what their corporate social responsibility objectives were, what markets they wanted to operate in, for community investment purposes and then the PT became almost a natural partner I think." (Senior Project Manager, PT)

The deliberation of partnerships can be the result of either a planned or an emergent process. As can be seen in the quotes above, the assessment of different partner options within the Partnership Selection phase was something of a planned process in both partnerships, but this assessment was supported by the historical evolution of a preexisting emergent relationship that had yet to coalesce into a formal partnership. Previous interactions between the partners included collaboration between regional offices or consultation on specialised issues.

Moving on to setting criteria for partnership selection a number of factors enabled the decision to partner with a particular organisation (table 2).

\section{Insert Table 2 here}

As we can see, there is considerable similarity in the criteria used in the two cases. For instance, the following quotes testify to the existence of broadly similar criteria of: cost effective relationships (money/time investment vs expected outcomes) in both instances:

So from the organisations' point of view it was obvious that if you had a large partnership with a company that perhaps had a five-year tenure and was financially 
larger, it was better for the organisation in terms of stability and long-term funding and so on. But also if you could get a major FTSE100 company to support you then that was like it would bring in others in similar types of partnership. (Ex-CEO Earthwatch)

“...the primary objective was we believed that our cash injection would help the Prince's Trust achieve a shift in the way it did things... the bank was looking for the right partner to do something with young people to help them into education, employment and enterprise which was our primary theme..." (Head of Community Investment, RBSG)

In partnership B the last stage of Partnership Selection was assessing the different NPO or BUS options. However due to reputational issues partnership A underwent more processes before finalising the selection of partners. Due to the previous high negative reputation of Rio Tinto, Earthwatch had to take another step: an informal risk assessment process. This involved an internal and an external risk assessment process but lacked a rigorous formal risk assessment process (Seitanidi, 2006a). The internal process consisted of a/ an internal debate among the employees of Earthwatch and b/ of a discussion between the employees of Earthwatch and Rio Tinto in order to respond to the Earthwatch employees concerns. The external process involved informal discussions with similar $^{3}$ NPOs to Earthwatch and a reliance on their risk assessment processes.

"I have to say our research wasn't very thorough... I think the only NGOs we spoke directly to would have been other NGOs in sort of our end of the spectrum of the environmental movement and we would talk to them and said... Like WWF but also, you know, people like the Natural History Museum and so on. And we would have asked them first whether they thought there were particular problems with RIO TINTO, whether they've done vetting themselves and so on. But secondly, whether if we entered a relationship with RIO TINTO that would make them regard us badly." (Ex-CEO, Earthwatch)

Within the informal risk assessment process an important aspect was the micro-political process that occurred within the organisation. The internal stakeholders of Earthwatch i.e. employees, trustees and members were informed about the discussions between the organisation and Rio Tinto (Seitanidi, 2006a). A small number of individuals within all three stakeholder groups raised concerns about the potential partnership relationship. For example the employees raised concerns with regards to the decision to form a close relationship with Rio Tinto: 
“... there was certainly resistance within Earthwatch to the partnership, as you know, because of the reputational issues of RIO TINTO and a number of colleagues at Earthwatch were members of Friends of the Earth and Greenpeace, where RIO TINTO has been regularly vilified rightly or wrongly for certain kind of things that it's done." (Executive, Earthwatch)

The concerns were managed informally and internally through the informal risk assessment process consequentially allowing for the further development of the relationship. Hence the selection phase is crucial in the implementation of the partnership as it needs to develop accountable decision making mechanisms that address the concerns of all stakeholders and which will allow for the next phase in the implementation process. Figure 2 offers an overview of the process of Partnership Selection based on the two case studies under examination.

\section{Insert Figure 2 here}

\section{Partnership Design}

The second phase identified is partnership design and this involves experimentation with the partnership relationship by setting up partnership objectives, drafting the Memorandum of Understanding ${ }^{4}(\mathrm{MoU})$ or a 'Heads agreement ${ }^{\text {"5 }}$, followed by a review process. Another area of partnership management is the partnership reporting and partnership structure, which usually involves several departments in both organisations. For example, in the case of Earthwatch, the Development Department originally turned the relationship into a partnership and the Corporate Programmes Department followed and actually carried out the relationship. In the case of Rio Tinto, the External Affairs Department developed the relationship and it was also responsible for the implementation of the partnership with the parallel involvement of the HR Department. Partnerships have been repeatedly described as "resource intensive" (Berger et al, 2004; Austin, 2000; Waddock, 1984) as they require a diverse resource mobilisation. In the case of partnership A resources were mobilised in two continents (due to the global character of the partnership) and involved four offices, Rio Tinto UK and Australia and Earthwatch Europe and Australia. The content of each partnership is presented in the Appendix, which indicates the spectrum of operations and resources that partnerships require. 
The first step in partnership design is partnership experimentation, which here involved drafting the MoU and agreeing partnership objectives. These are crucial steps in terms of how the partnership plays out over time, and it was interesting to observe the experimentation and negotiation that went into this stage. For example, in the case or Rio Tinto-Earthwatch, the company tried to devise a unified global MoU, but half way, through the process realised that due to the legal differences ${ }^{6}$ in each country it would have been impossible. Hence two different MoUs were devised, one signed in Australia among the partners and one in the UK.

Partnership reporting is a standard practice that consists of drafting internal documents to assist in clarifying the position of each organisation; the aims and objectives of the partnership; the financial and non-financial exchanges among the partners; and touch upon issues that need to be addressed within the relationship. An interesting observation that was shared across both partnerships was that reports were compiled only from the NPO and submitted to the BUS. The one-way reporting reflects a pre-CSR reality of interaction between a BUS and a NPO that dominated transactional relationships such as sponsorship and earlier corporate philanthropy (Seitanidi and Ryan, 2007). Some of the Royal Bank of Scotland executives appeared to expect their Prince's Trust counterparts (even if both people were members of the partnership teams) to report to them as they would expect an agency they were paying to do so. Although this issue was raised by Prince's Trust employees it appeared that the Royal Bank of Scotland did not take any further corrective action.

An important element of the partnership design is establishing a "virtual team", related to the structure of the relationship. In the first partnership the virtual team comprised only of few individuals and was not as elaborate, well structured and operationalised as in partnership B. Hence the description below is based on the Prince's Trust- Royal Bank of Scotland partnership. Employees within the virtual team of Prince's Trust and the Royal Bank of Scotland acted as counterparts in each others' organisations. The 'virtual team' allowed for: 1/ multiple points of reference within each partner's organisation consisting of a wide spread network of people, 2/ development of trust among the virtual team members and in effect among the two organisations, 3/ avoiding over centralised power in one or two individuals in each organisation, 4/ better operationalisation of the 
partnership. Another important element of the virtual team is the background of its members.

“... both (name of RBS team leader) and (name of head of RBS community investment team) come from non-traditional backgrounds which have involved community work. ..., so they're not pure bank backgrounds. .... Actually that's been extremely helpful to me and I think to other people in the organisation ...” (Route 14-25 Manager, Prince's Trust)

Interestingly the virtual team was deemed by informants to consist of a "new breed of executives” whose professional backgrounds might be not only within the business sector but equally within the public and voluntary sectors. Figure 3 below demonstrates the relationship across the two virtual teams. For example, circle number six in Prince's Trust represents the 'Communications manager' that had a direct relationship with circle six which is the 'Media relations manager' at Royal Bank of Scotland's virtual team. The reason they share the same digit is because they mirrored each other's function and responsibilities with regards to the partnership and in fact the impression during the interviews was that the Royal Bank of Scotland counterparts acted almost as second line managers to their Prince's Trust counterparts. The numbers represent the range of different functions within the partnership team of each organisation. Number 9 in both organisations represents the role of Senior Project Manager at Prince’s Trust and the Community Investment Manager at the Royal Bank of Scotland. Both are central to the partnership function as they play a vital role in project managing the relationship, its processes and outcomes. These two people are informed about everything (with regards to the partnership) within their own organisation (e.g. line 6-9) but also in each other's organisations (e.g. line 9-9).

\section{Insert Figure 3 here}

The virtual team's role is also to introduce and understand each other's organisation, which is very important especially for complicated organisations such as the Royal Bank of Scotland. Hence the virtual team also functions as a steering wheel for enhancing the organisations’ knowledge and understanding. 
“...we all do respect each other a tremendous amount. And sort of trust each other to do things. ... so like people, micromanaging, you don't get that so much because we're all left to do our own set of things. And if I need advice on something or how to do something, I'll go to (Community Investment Manager's name) and ask "what's the best way to do this within your organisation?" you know... And talk things through. We do have a very open relationship with them.” (Employee Investment Manager, Prince's Trust)

The virtual teams in each organisation developed close relationships that sometimes extended to the personal level. As the relationships within the virtual team members evolved it could even be the case that they might feasibly become uncoupled from the rest of the organisation. This could potentially cause tensions between the virtual team members and their own organisation. The degree of embeddedness of the partnership within each organisation can play an important role by gradually allowing other parts of the organisation to evolve in parallel ways.

Finally, the next stage is the operationalisation of the partnership, which allows for the gradual stabilisation of the partnership content and processes. Some of these processes include: the partnership reporting, the review meetings (bi-weekly partnership management meetings and annual review meetings (in the case of partnership B twice a year in order to monitor and evaluate the progress of the partnership) and the structure of the partnership relationship. Figure 4 below summarises the partnership design and its respective stages.

\section{Insert Figure 4 here}

In partnership B the relationship became operationalised much earlier due to the stronger compatibility between the partners and the lack of immediate reputational risks. As a result the first (experimentation) and second (adaptation) steps were incorporated in one phase.

\section{Partnership Institutionalisation}

The final stage of implementation refers to the level of partnership institutionalisation within the organisations; in other words the extent to which the partnership, its 
programmes, and processes become accepted as part of the organisations involved. In the Earthwatch-Rio Tinto partnership (A) although the relationship was tested through internal crises and survived, the organisational actors expressed their reservation with regards to the instutionalisation of the relationship. They appeared to believe that the relationship was more dependent on personalities than on the level of institutionalisation:

"Ideally, one would like these things to be institutionalised so that the personalities don't matter, but I think, inevitably, they do. There has been a change of person in Earthwatch and partnership is no longer what it was. It's no longer as dynamic and creative. So, yes, it does matter." (Corporate Relations Manager, Rio Tinto)

Hence at the time the data collection was complete for the first partnership the relationship was facing an institutionalisation challenge. However in the case of partnership B the partnership was fully institutionalised as the partnership content and processes became embedded in both organisations.

The first test of embeddedness or institutionalisation of the partnership relationship is assessing the impact of crises within the organisations. When a relationship has been institutionalised it means that although crises occur, they can be resolved rather than cause a serious problem in the relationship. A number of interviewees referred to a total of fifteen incidents that describe situations that could be categorised as 'crises situations'. However, both organisations dealt with these incidents in a 'mature' way that offers testimony to the quality but also the stage of the relationship. Unfortunately, most incidents are classified as 'off the record' and thus quotes can not be used to illustrate the above point. Some of the incidents relate to the Prince's Trust target group and some are random events that could have taken place in any organisation. The quote below testifies that $a$ / such incidents occur and $b$ / the mature reaction on behalf of the bank:

“... I think, you know, because they are very understanding, and they do appreciate that these things happen ...” (Senior Project Manager, Prince’s Trust)

This also testifies the respect of each partner and its own incubation times until results are achieved or processes are put in place. 
The second test of partnership embeddedness is the extent to which members of both organisations refer to the relationship by using the personal pronoun in the first plural form "we” instead of 'us' and 'them'. The "we" mentality is central to the reactions of the organisations and the level of personal familiarisation that occurs in this stage of the relationship:

“...these guys all work as one team and I went to a meeting and I couldn't have told you who was Royal Bank and who was Prince's Trust ...” (Sponsorship Manager, Royal Bank of Scotland)

Another observation regarding the central teams or virtual teams of the partnership is that they function as 'breakwater' for the incidents that occur. Since the members in both teams have developed a higher level of familiarisation for each others organisations their level of tolerance is higher among employees within the rest of the organisation. However, the dissemination of understanding is not shared equally across all people within each organisation, providing further evidence for the existence of a subculture:

"...It is very good and is very promising that in terms of their internal communications is not necessarily that ... not everyone shares that view, you know, (not) everyone is as progressive as the central team ....” (Senior Project Manager, Prince’s Trust)

The 'core people' of the partnership enjoy the familiarization benefits among which: 1/ ask each other for advice, 2/ encourage new ideas and assist in their implementation, 3/ increase their contacts through the networks of their partner organisation. The familiarisation process is also actively encouraged by both organisations. More specifically an 'away day' was organised that allowed the members of the virtual team to further develop their understanding and get to know other members of the virtual team rather than only their counter-parts:

"And that was really nice and it was really good to see that ... is like really committed, really into it, really enthusiastic about what they are doing ... and we were able to sort of have a good laugh and we joked each other about stuff. And that was really nice.... And that was just for one day. And everyone I'm sure ... I think everyone came away from that feeling about although everyone was quite motivated beforehand I think they came away from that feeling... Because they knew everyone who's kind of behind it ..." (Executive, Prince's Trust). 
An important observation is that the partnership institutionalisation makes sense on the personal level, i.e. when individuals develop a personal relationship of trust within the partnership then the level of embeddedness of the relationship becomes more evident. However, the partnership institutionalisation does not refer only to the agreement between the two partners, but also to their ability to disagree without causing termination of the relationship. The following quote offers an example of such incident.

“... and also there's one project where the bank had signed up, or part of the bank had signed up to do something with The Trust. ... The Trust appointed the individual, but then had them do a different job and we said, well hang on that's not what we funded, so The Trust actually returned the money ..." (Head of Community Investment, Royal Bank of Scotland)

The above incident testifies the level and quality of the institutionalisation. Even when the organisations do not agree in their approach to a specific issue they are allowed to disagree and function in an autonomous way without consequences that might jeopardise the relationship viability. This is an important element of the partnership relationship: to disagree within the partnership.

\section{Insert Figure 5 here}

Figure 5 summarises the institutionalisation stage of the partnership relationship. The first stage appears to involve overcoming crises in two ways: a/ by accepting the other organisation's strengths but also weaknesses as a reality of an integrative relationship and b/ by not avoiding conflict but rather accept disagreements as functional which permits retaining the organisation's identity intact. The first stage is termed 'relationship mastering' and the second 'personal familiarisation' involving the familiarisation on the personal rather than organisational level. Incidents of spending informal time with each other were reported by interviewees such as having lunch together or staying to somebody's else's house and so forth.

The final section of the paper discusses the findings and draws conclusions with regards to the implementation of partnerships. 


\section{The Challenge of CSR-Partnerships}

The paper explored deep level partnership processes in order to extend our knowledge of CSR implementation within the profit and nonprofit sectors. The results were based upon two in-depth case studies of long-term and high profile partnerships (see partnership overview in Appendix) both from the UK, but involving a broad range of contexts and issues.

The complete model of implementation that we have developed from this analysis and informed by the practice is presented in Figure 6. The three phases within implementation (selection, design, institutionalisation) are followed by exit strategy, although exit was not evident in either of the case studies under investigation. However, an exit strategy would be the final implementation phase of partnership if it is to be terminated. The partnership review process can take place as part of the exit strategy or during the institutionalisation phase and can feedback and inform all phases of the relationship.

\section{Insert figure 6 here}

This model demonstrates that beyond the simple stages of partnership implementation, there are numerous management challenges to face every step of the way. These include: the determination of effective criteria for partner selection, designing appropriate risk assessment techniques, experimenting with and adapting agreements, objectives, reporting mechanisms and other systems, managing crises to the benefit of the partnership, and balancing the necessary personal relationships with needs for on-going organizational institutionalisation.

The partnership selection phase can be an emergent or a planned and systematic process or it can be a combination of emergent/planned process as indeed is the case in many real world strategies (Mintzberg and Waters, 1985). Setting criteria for partnership selection can reveal organisational priorities. Since this is a 'behind-the-doors' process it requires research by both partners in order to penetrate the rhetorical statements that aim to 
impress. In particular in cases where partnering is a planned process, the process of trying to identify who is the 'right' partner might have similarities to 'blind-dating' - hence the need for research and a prolonged selection phase. Based on the overall study on NPOBUS partnerships in the UK, including the two case studies presented in the paper, it appears that it is the NPOs that have a higher reputational risk by partnering with BUSs. In the case of partnership A the informal risk assessment process was a necessary step as the BUS partner had a high reputational risk. An institutionalised and formal risk assessment process could however have allowed for all stakeholders to voice their concerns in order to reach an inclusive and representative decision. In large organisations this might have increased difficulties, and its success can be dependent on the necessary internal structures being in place, but in terms of implementing CSR, accountability to relevant stakeholders is an essential element

Partnership design phase can be summed by the phrase 'trial and error'. Drafting an MoU can be a lengthy process as it incorporates setting up partnership objectives and other partnerships processes such as initiating a virtual team across the two organisations and deciding on partnership programmes. Across all the cases studied there was no indication of any two-way reporting, i.e. that the BUS reported to the NPO. This can be a reflection of a partnership relationship being on a transactional stage (Austin, 2000) with the power dynamics favouring only the BUS partner (Seitanidi and Ryan, 2007) and limited institutionalised two-way learning

Reaching the partnership institutionalisation is a lengthy process that some organisations might never arrive at, which in some cases can be a positive outcome: a/ the relationship was terminated as it was not good for either partner; b/ the partnership objectives were accomplished prior the institutionalisation phase. In the latter case it might be necessary to revisit more fundamental questions such as: what is the type of relationship that we are interested to develop and why? Austin (2000) offers a comprehensive list of questions that can inform organisations entering in a partnership relationship.

Partnerships are new emergent institutions that exist as flexible forms of organising with little or no formal legal status, and demonstrate virtual structures across organisational boundaries and countries. Therefore, they require new skill sets and a progressive 
appreciation of organising. Some of the skills required are already in existence: an experiential understanding of all three sectors (public, profit and nonprofit) which marks the 'new breed of executives' that are able to span all three sectors rather than have traditional mono-sectorial backgrounds; virtual networking skills that facilitating not only partnership operationalisation but also the phase of institutionalisation that takes place both on a virtual and physical space. However, there is a need for different types of skills that some of the organisations examined seem to lack, such as a generalised ability to sustain conflict within a collaborative relationship and the development of experience in non-structured relationships based on continually emerging processes.

It is worth noting that whilst the cases we reported on here are generally regarded by both their participants and outsiders as successful, they clearly do not represent unreservedly best practice in partnership implementation. Our analysis reveals several areas where improvements could be made, for example in developing more formal and effective risk management tools, or creating more symmetrical reporting processes. However, in both cases, a willingness to learn and adapt, and an ability to remain agile in the context of a new strategic initiative meant that despite the emergence of problems, shortcomings, and even crises, the partnerships persisted over time and appeared to enjoy continued broad support from the participating organizations.

The findings presented in the paper also suggest that various underlying management issues arise in the implementation of partnership, namely: reputational (depending on the organisational reputation prior and during the relationship), legal (with regards to the $\mathrm{MoU}$ ), accountability (risk assessment procedures), economic (different allocation of funding within the partnership might result in returning funds to the BUS partner) and cultural (in the early stages of the relationship the partners might not be able to communicate due to different use of 'languages' based on their different sectorial realties) issues. Some of the above issues are highly contextualised (policies, language, accountability procedures) depending on the particularities of each partnership; however it will suffice if partnership managers are at least vigilant on the type of management issues that might arise. 
The managerial implications for NPOs include the need to institutionalise risk assessment processes for the selection stage in order to safeguard accountability and legitimacy in their decision making, especially in cases where NPOs represent 'voiceless stakeholders' such as the environment, children and so forth (Crane and Matten, 2007). Furthermore, managers in both NPOs and BUSs need to develop and nurture skills that facilitate the process of partnering. We suggest a two item partnership 'test' for managers during the development of the relationship as a rudimentary indicator of implementation effectiveness (i.e. not an indicator of partnership effectiveness more broadly, merely of its implementation). The first measure refers to the accountability of the implementation and the second to the institutionalisation of the relationship. In the Partnership Test (Table 3) the first column presents the criterion to be tested, the second the suggested procedures that need to be undertaken in order to answer the final questions (column 3). The partnership test can assist managers in reflecting on the partnership relationship by understanding better the dynamics with their partners and the effectiveness of the skills they have or they need to develop.

\section{Insert table 3 here}

Further research can examine the processes that take place within all three chronological stages of partnerships: formation-implementation-outcomes (Selsky and Parker, 2005), rather than just within the implementation stage. Research is necessary on the exit strategy of cross sector partnership as an option within the partnership relationship by examining the motivations behind it and as process of terminating a long-term relationship. The development of skills as a result of partnership and as required by partnerships is another area of interest which can be further explored in order to inform both practice and theory.

Ultimately though, this paper contributes to the literature of partnerships by offering a practice-tested stage model for the partnership selection, design and institutionalization phases that adds detail and clarity on the micro-processes that are being presented. It also contributes to the CSR literature as it builds the connection between socially responsible practices within BUSs and NPOs during partnership implementation. Finally, it 
contributes to the practitioner audience a practical partnership test to assist in determining the quality of the efforts and the impact of the processes in place.

\section{References}

Accountability: 2007, Partnership Governance and Accountability (PGA). Accountability's website, available from:

http://www.accountability21.net/research/default.asp?pageid=107

Accessed: $4^{\text {th }}$ February 2007.

Alvarez, M., Binkley, E., Bivens, J., Highers, P., Poole, C., \& Walker, P.: 1990. Casebased instruction and learning: An interdisciplinary project, Proceedings of 34th Annual Conference (pp. 2-18), College Reading Association. Reprint.

Andriof J.: 2000, Managing Social Risk through Stakeholder Partnership Building. PhD Thesis, Warwick University.

Austin, J.: 2000, The Collaboration Challenge: How Nonprofits and Businesses Succeed Through Strategic Alliances. San Francisco (Jossey-Bass Publishers).

Berger, I. E., Cunningham, P. H. and Drumwright, M.E.: 2004, 'Social alliances: Company/Nonprofit Collaboration’, California Management Review, 47(1), 58-90.

Bryson, J.M., Crosby, B.C., and Middleton Stone, M.: 2006, 'The Design and Implementation of Cross-Sector Collaborations: Propositions from the Literature', Public Administration Review, 66, 44-55.

Burke L., and Jeanne M. Logsdon, J. M.: 1996, 'How Corporate Social Responsibility Pays Off. Long Range Planning’, 29(4), 495-502.

Carriga E. and Mele, D.: 2004, 'Corporate Social Responsibility Theories: Mapping the Territory’, Journal of Business Ethics, 53, 51-71.

Clarke, A.: 2007a. Cross Sector Collaborative Strategic Management: Regional Sustainable Development Strategies. Presentation at the Scoping Symposium: The Future Challenges of Cross Sector Interactions, May 24, 2007, London , England .

Clarke, A.: 2007b, Furthering Collaborative Strategic Management Theory: Process Model and Factors per Phase. Conference Proceedings: Sprott Doctoral Symposium, April 19-20, 2007, Ottawa , Canada .

Covey, J. and L. D. Brown: 2001, Critical Co-operation: An Alterative Form of Civil Society-Business Engagement, IDR Reports. Volume 17, No.1. Institute for Development Research. London. 
Crane A, Matten D.: 2007. Business Ethics: Managing Corporate Citizenship and Sustainability in the Age of Globalization, Second edition (Oxford University Press: Oxford).

Earthwatch: 2004, Earthwatch's mission. Earthwatch website. Available from:http://www.earthwatch.org/europe/aboutus.html, Accessed: 3 July 2004.

Earthwatch: 2002, Implementing Corporate Environmental Responsibility, Directory of members of the Corporate Environmental Responsibility Group 2002-3003, Bulletin No.20, (Oxford: Earthwatch).

Earthwatch: 2001, Earthwatch Annual Report 2001, (Oxford: Earthwatch Institute).

Flick, U.:1998, An Introduction to Qualitative research, (London, Sage Publications).

FTSE4GOOD: 2006, FTSE4GOOD Index Series, Inclusion Criteria. FTSE The Index Company: London. Available from:

http://www.ftse.com/Indices/FTSE4Good_Index_Series/Downloads/FTSE4Good_Inclusi on_Criteria_Brochure_Feb_06.pdf

Accessed: July 2006.

Global Compact: 2006, The Global Compact Network webpage, Accessed: 26 ${ }^{\text {th }}$ December 2006, Available from:

http://www.unglobalcompact.org/ParticipantsAndStakeholders/index.html

Global Reporting Initiative: 2006, Annual Review of Activities, (Amsterdam: GRI).

Godfrey , P.C. and Hatch, N.W.: 2007, 'Researching Corporate Social Responsibility: An Agenda for the $21^{\text {st }}$ Century’, Journal of Business Ethics, 70, 87-98

Googins and Rochlin: 2000, 'Creating the Partnership Society: Understanding the Rhetoric and Reality of Cross Sector Partnerships', Business and Society Review, 105(1), 127-144.

Hilson, C.: 2002, 'New social movements: the role of legal opportunity. Journal of European Public Policy', 9(2), 238-255.

McCann, J. E.: 1985, 'Design Guidelines for Social Problem-Solving Interventions. The Journal of Applied behavioural Science’, 19(2), 177-189.

McCann, J. E.: 1985a, 'Reply to Professor Chiles', The Journal of Applied behavioural Science, 19(2), 191-192.

Mintzberg, H.: 1993, 'The Pitfalls of Strategic Planning', California Management Review, 36(1): 32-47.

Mintzberg, H, and Waters, J.A.: 1985, 'Of Strategies, Deliberate and Emergent. Strategic Management Journal’, 6(3): 257-273. 
Mir, R., Kashyap, R. and Iyer, E.: 2006, 'Toward a Responsive Pedagogy: Linking Social Responsibility to Firm Performance Issues in the Classroom', Academy of Management Learning \& Education, 5(3), 366-376.

Pettigrew, A.: 1985, 'Contextualist research and the study of organisational change process', In: Mumford, Hirscheim, Fitzerald and Wood-Harper (Eds), Research Methods in Information Systems. Proceedings of the IFIP WG8.2 Colloquium, Manchester, UK, 13 September 1984, (Elsevier Science Publishers B.V).

Pressman, J.L., and Wildavsky, A.B.: 1973, Implementation, (Berkeley: University of California Press).

Ragin, C. C. and Becker, H. S.: 1995, What is a Case? Exploring the Foundations of Social Inquiry, 3rd Edition (Cambridge: Cambridge University Press).

Rio Tinto: 2002. Social and environmental review highlights. London, Rio Tinto.

Seitanidi, M.M., and Ryan, A.: 2007. Forms of Corporate Community Involvement: From Philanthropy to Partnerships. A Critical Review. International Journal of Nonprofit and Voluntary Sector Marketing, (in press).

Seitanidi, M. M.: 2006. Partnerships between Nonprofit Organisations and Businesses in the UK. A Critical Examination of Partnerships. PhD Thesis. University of Nottingham, International Centre for Corporate Social Responsibility (ICCSR), Nottingham.

Seitanidi, M.M.: (2006a), Covert Political Conflict in Non-Profits Organisations in the stage of Partnership Selection: Challenges from within. The Case of Earthwatch - Rio Tinto Partnership, in 10th Annual Conference of the European Business Ethics NetworkUK Association (EBEN UK) and 8th Ethics and Human Resource Management Conference, 11th -12th April 2006, Cambridge, UK.

Seitanidi, M. M.: 2005, 'Corporate Social Responsibility and the Non-Commercial Sector’, New Academy Review, 3 (4), 60-72.

Selsky, J.W. and Parker, B.: 2005, 'Cross-Sector Partnerships to Address Social Issues: Challenges to Theory and Practice', Journal of Management, 31(6): 1-25.

Schuler, D. A., and Cording, M.: 2006, 'A Corporate Social Performance-Corporate Financial Performance Behavioral Model for Consumers', Academy of Management Review, 31(3), 540-558.

Waddock, S.: 1989, 'Understanding Social Partnerships. An Evolutionary Model of Partnership Organisations’, Administration \& Society, 21(1): 78-100.

Waddock, S. A.: 1988, 'Building Successful Partnerships', Sloan Management Review, Summer 1988, 17-23.

Westley, F., and H. Vredenburg: 1997, 'Interorganisational Collaboration and the Preservation of Global Biodiversity’, Organisation Science, 8 (4), 381-403. 
Wilson a. and Charlton K.: 1993, Making Partnerships Work, (London: J. Roundtree Foundation).

\section{APPENDIX}

Please insert Appendix HERE (attached document with table) 
TABLE AND FIGURES

\section{Figure 1: Cross Sector Social Partnerships}

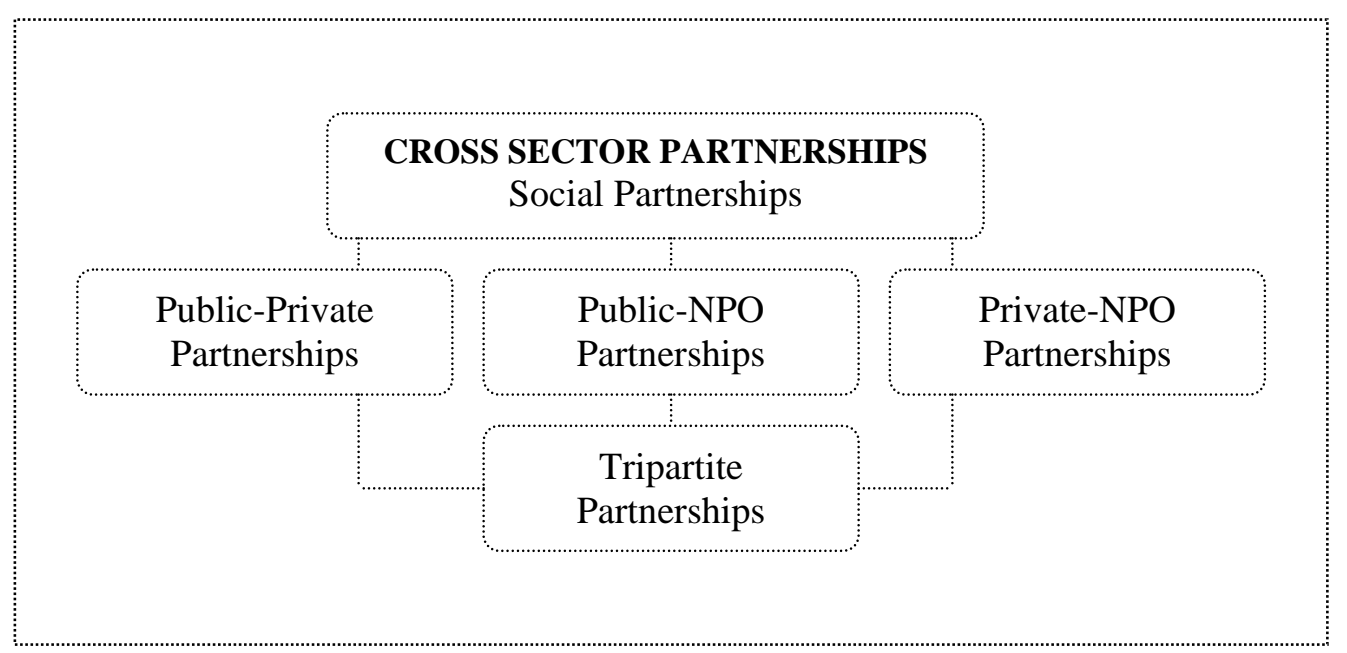

Table 1: Criteria for Selecting the Cases

\begin{tabular}{|l|l|l|l|l|l|l|}
\hline & Form & $\begin{array}{l}\text { Scope of } \\
\text { activity }\end{array}$ & Purpose & Resources & Reputation & $\begin{array}{l}\text { Style of } \\
\text { activity }\end{array}$ \\
\hline Earthwatch & NPO & International & $\begin{array}{l}\text { Environmental } \\
\text { issue }\end{array}$ & All & Medium & Collaborative \\
\hline Rio Tinto & BUS & International & $\begin{array}{l}\text { Environmental } \\
\text { issue }\end{array}$ & All & $\begin{array}{l}\text { High } \\
\text { Negative }\end{array}$ & Collaborative \\
\hline $\begin{array}{l}\text { Prince's Trust } \\
\text { Scotland }\end{array}$ & NPO & National & Social issue & All & High & Neutral \\
\hline
\end{tabular}


Table 2: Enabling Factors for Assessing Partner Suitability

\begin{tabular}{|c|c|}
\hline $\begin{array}{c}\text { Partnership A: } \\
\text { Earthwatch - Rio Tinto }\end{array}$ & $\begin{array}{l}\text { Partnership B: } \\
\text { Prince’s Trust-Royal Bank of Scotland }\end{array}$ \\
\hline $\begin{array}{l}\text { - Previous experience working across } \\
\text { different economic sectors }\end{array}$ & $\begin{array}{l}\text { - Previous experience working across } \\
\text { different economic sectors }\end{array}$ \\
\hline $\begin{array}{l}\text { - Covering similar geographical areas (with } \\
\text { headquarters both organisations in } \\
\text { Melbourne-Australia and in London-UK) }\end{array}$ & $\begin{array}{l}\text { - Covering similar geographical areas (RBS } \\
\text { has branches all over the UK as well as } \\
\text { Prince's Trust has regional offices) }\end{array}$ \\
\hline $\begin{array}{l}\text { - Cost effective relationship (money/time } \\
\text { investment vs expected outcomes) }\end{array}$ & $\begin{array}{l}\text { - Cost effective relationship (money/time } \\
\text { investment vs expected outcomes) }\end{array}$ \\
\hline $\begin{array}{l}\text { - 'Safe' profiling platform (within BUSs or } \\
\text { NPOs) }\end{array}$ & $\begin{array}{l}\text { - 'Safe' profiling platform (within BUSs or } \\
\text { NPOs) }\end{array}$ \\
\hline - Similar time scales of operation & - $\quad$ Both organisations had Royal affiliations \\
\hline - Mutual interests : biodiversity & $\begin{array}{l}\text { - Mutual interests: social exclusion; business } \\
\text { start-ups }\end{array}$ \\
\hline across the two organisations & $\begin{array}{l}\text { - Personal chemistry among the core people } \\
\text { across the two organisations }\end{array}$ \\
\hline
\end{tabular}

Figure 2: Partnership Selection Stages

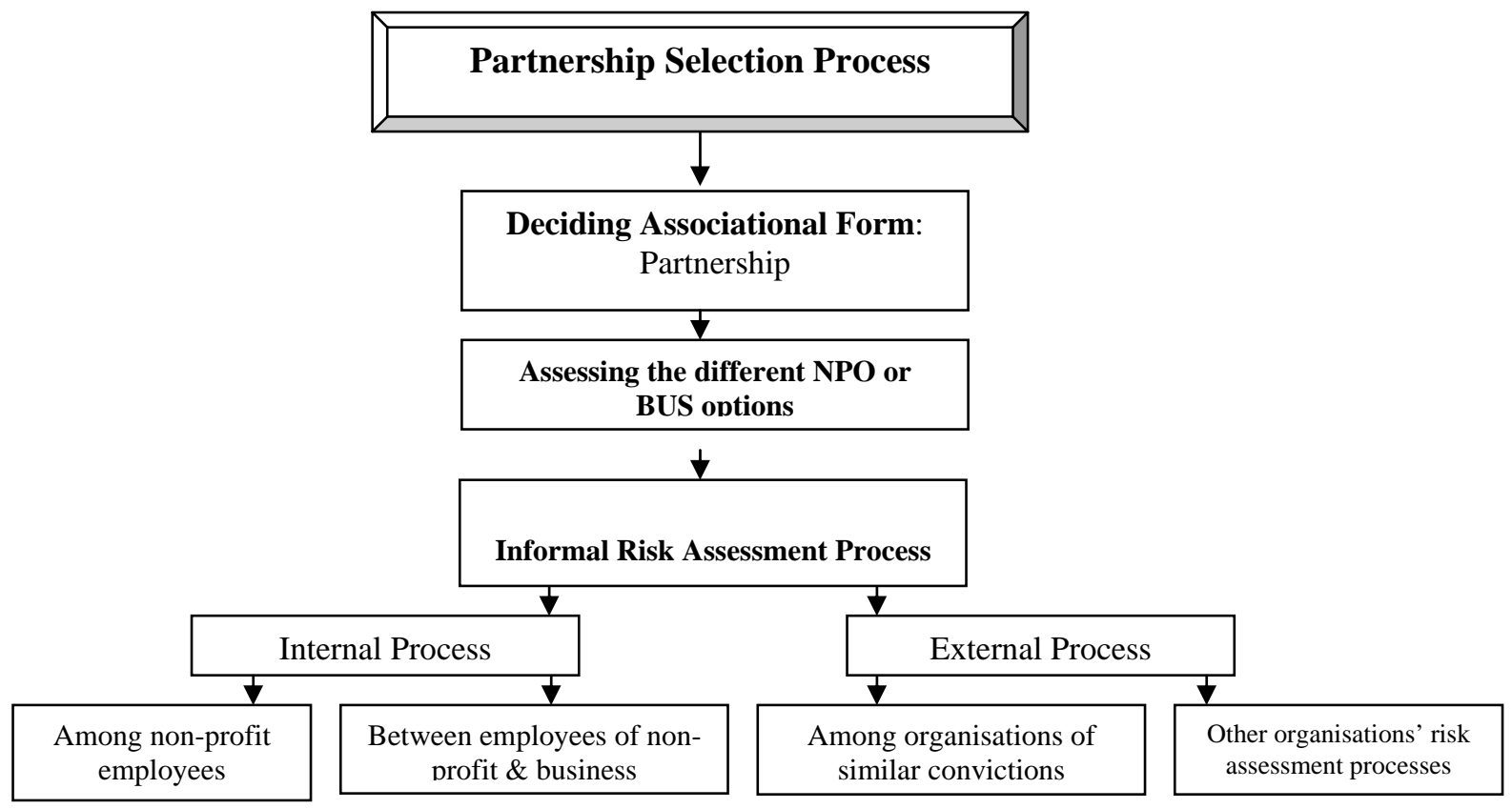


Figure 3: The Virtual Teams - Prince's Trust-RBSG Partnership

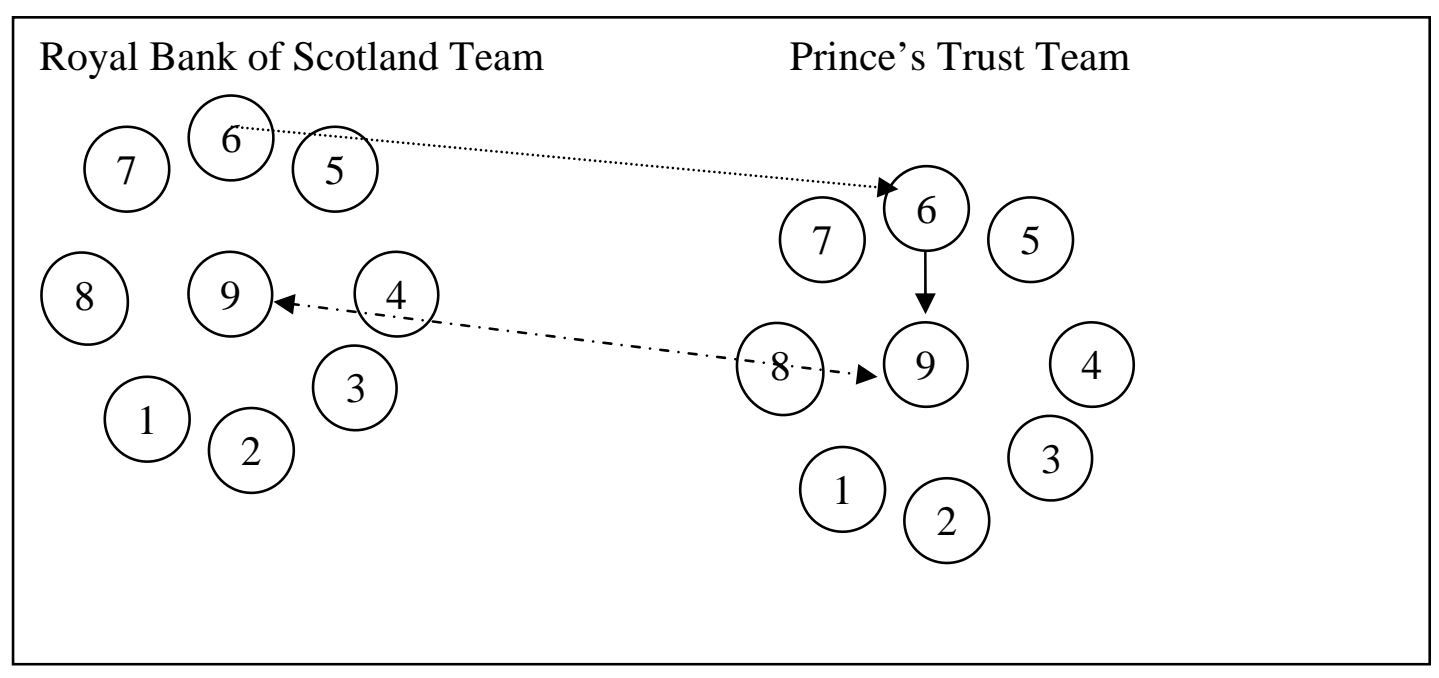

Figure 4: Partnership Design Stages

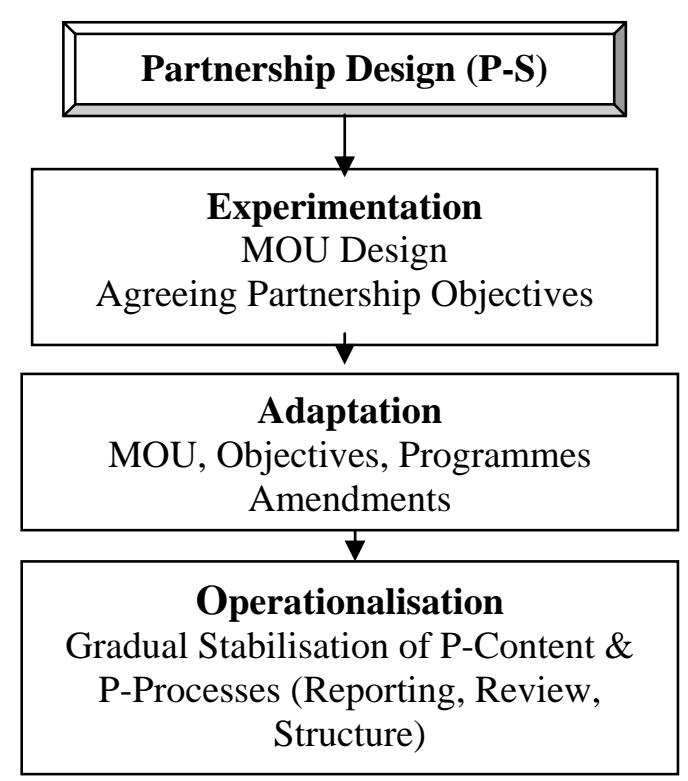


Figure 5: Partnership Institutionalisation

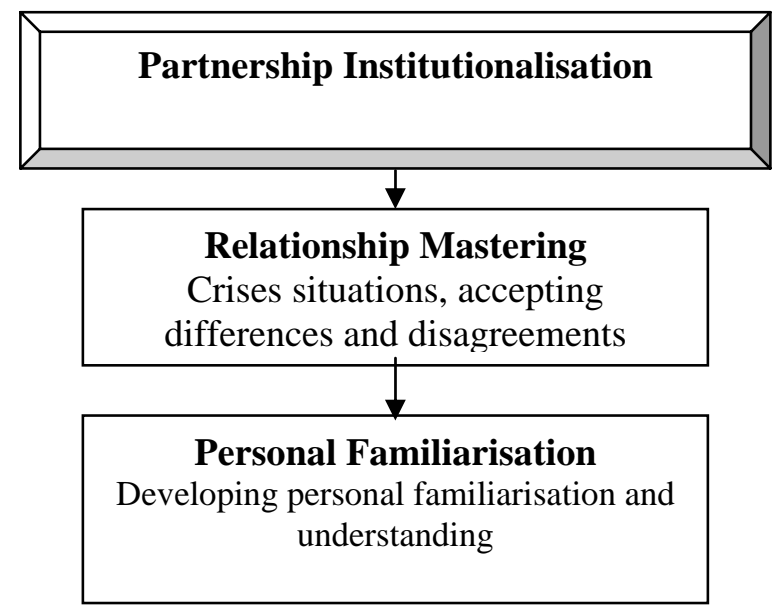




\section{Figure 6: Partnership Stages}

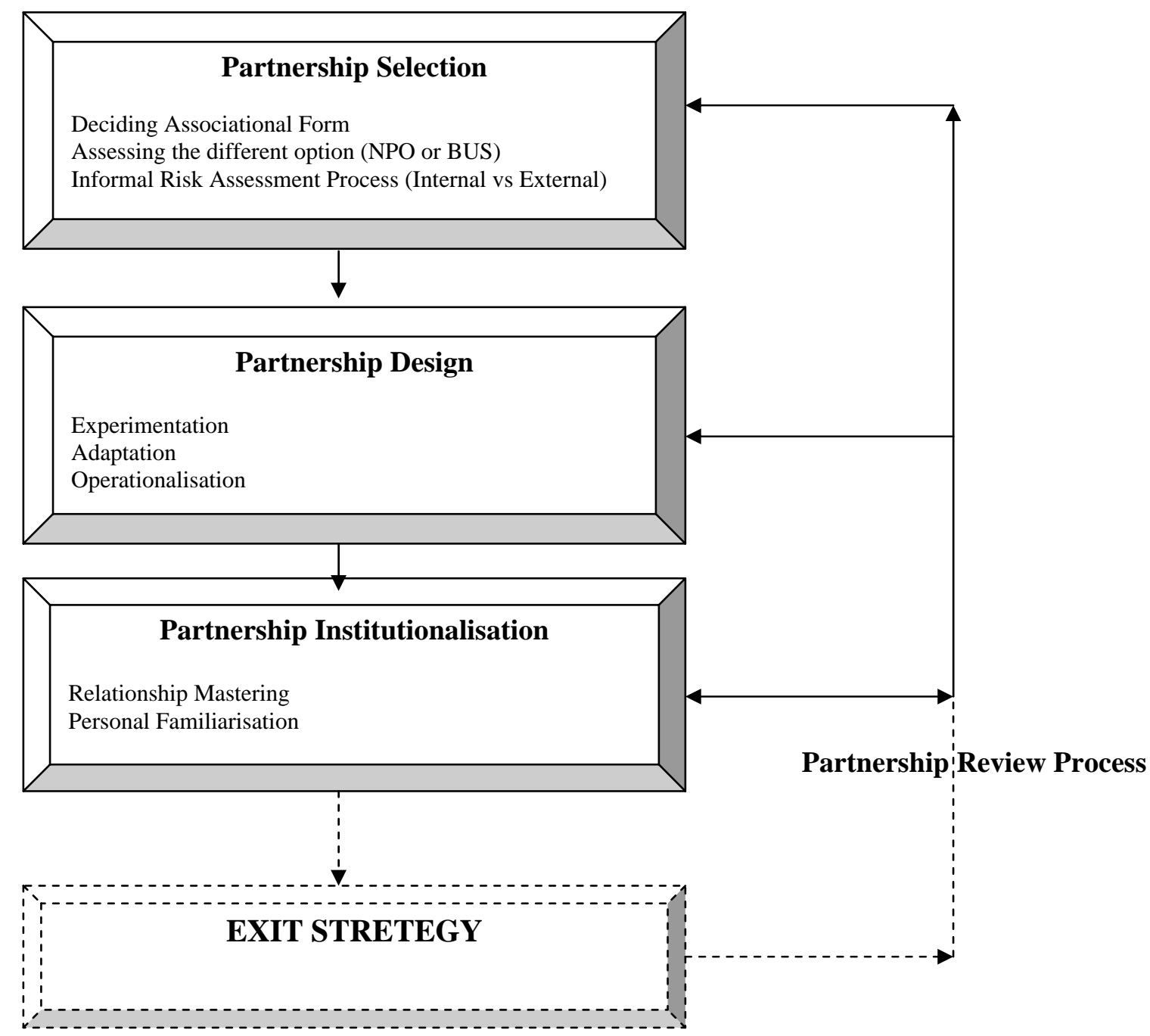


Table 3: The Partnership Test

\section{THE PARTNERSHIP TEST}

\begin{tabular}{|c|c|c|}
\hline CRITERION & PROCEDURES & QUESTION \\
\hline $\begin{array}{l}\text { 1/ Accountability } \\
\text { The external } \\
\text { environment of the } \\
\text { partnership }\end{array}$ & $\begin{array}{l}\text { Accountability mechanisms in place: } \\
\text { - List the social responsibilities } \\
\text { during the different phases of } \\
\text { partnership implementing } \\
\text { - List al the stakeholders to which } \\
\text { the partnership needs to be } \\
\text { accountable to }\end{array}$ & $\begin{array}{l}\text { Is the Partnership Implementation } \\
\text { Accountable? }\end{array}$ \\
\hline $\begin{array}{l}\text { 2/ Institutionalisation } \\
\text { The internal } \\
\text { environment of the } \\
\text { partnership }\end{array}$ & $\begin{array}{l}\text { Institutionalisation of the relationship: } \\
\text { - List the crises situation that took } \\
\text { place in the partnership } \\
\text { implementing and their impact in } \\
\text { the relationship } \\
\text { - Undertake an informal audit of the } \\
\text { members of staff a/ who are } \\
\text { members of the partnerships team } \\
\text { and b/ who are not members of the } \\
\text { partnership team and record if they } \\
\text { refer to the partnership as 'we' or } \\
\text { 'us' when referring to the } \\
\text { relationship }\end{array}$ & $\begin{array}{l}\text { Is the Partnership Institutionalised } \\
\text { within the organisation? }\end{array}$ \\
\hline
\end{tabular}

\section{Endnotes}

1 This research focuses on Earthwatch Institute Europe and not on the whole network of Earthwatch organisations. Hence, the word "Earthwatch” refers to Earthwatch Institute Europe, unless otherwise stated. Earthwatch US was established in 1973, followed by the Earthwatch Australian (established in 1982), Europe (established in 1985), and in Japan (established in 1991) (Earthwatch, 2002: 46)

${ }^{2}$ One of the interviews was with Partizans, a confrontational and sole issue NGO that focused its critical attention to Rio Tinto’s operations worldwide.

${ }^{3}$ Similar refers to NPOs that are co-operative towards businesses.

${ }^{4}$ In Partnership A an MoU was drafted which was unclear to some organisational actors whether this was a legally binding document or not.

${ }^{5}$ In Partnership B a similar document existed which was termed 'Heads agreement'. The confusion within the partners was whether a 'contract' existed at all or if the partnership was based on informal discussions among top executives within both organisations.

${ }^{6}$ One of the differences is that if in the UK if you describe in your MoU the fact that one of the objectives of the partnership is for the company's benefit, then the partnership is considered a sponsorship and therefore is subject to VAT. This is not the case in Australia. 